\title{
The Recent changes in the Drill of the German Army
}

\section{Colonel Lonsdale Hale Ret. R.E.}

To cite this article: Colonel Lonsdale Hale Ret. R.E. (1889) The Recent changes in the Drill of the German Army, Royal United Services Institution. Journal, 33:148, 567-601, DOI: 10.1080/03071848909416504

To link to this article: http://dx.doi.org/10.1080/03071848909416504

$$
\text { 册 Published online: } 11 \text { Sep } 2009 .
$$

Submit your article to this journal $\sqsubset x$

Џ Article views: 3

Q View related articles $\widetilde{2}$ 
Wednesday, April 3, 1889.

Gexeral G. FRSKINE, Chairman of the Council, in the Chair.

\title{
THE RECENT CHANGES IN THE DHILL OF THE GERJIN ARIIY.
}

\author{
By Colonel Loxsdale H.ıLe, Ret. R.E.
}

Ix the year 1872, shortly after the termination of the Franco-German War, tho latest changes made by the Prussiaus in their Infantry Wrill Book formed the subject of a lecture delirered in this theatro by tho late 3Iajor E. M. Jones. In 1876, a new cdition of the Infantry Urill Regulations of tho Prussian Army and officially called a "reprint" of tho old Regulations which bore the d:ato 25th Sep. tember, 18.17, was issued to the Aruy. The leading features of the " reprint," and the alterations it introduced aro given in a paper coutributed to the Occasional Notes in the 88th number of the Jour'nal, ${ }^{1}$ by Lieutennnt-General (then Colonel) E. Nerrdigate, now commanding in Bermudn. The Council of this Institution, when arranging the proeriamme of lectures for the carrent session, had before them the desirableness of bringing the iuformation on this subject up to the present time. They consider that the lectures delirered here should not only deal with matters of passing interest, but should be standard sources of reference in future yenrs. Inasmnch then as a fresh edition of the Drill Regulations was issued in September of last year, and morcover the publication of this edition dlew on it the nttention and criticism of soldiers all over Europe, the Conncil determined to include in their programme a lecture on it. Mlost unfortunately, however, owing to causes to which it is unnecessney to refer, diffieulties arose which resulted in the withdrawal of the lecture. Strongly impressed with the desirableness of this particular subject beiug brought before the members of the Institution, I undertook to obtrin nnother lecturer. Iut the difficulty of finding one was very great, for English Officers who really understand technical military German are few and far between. It so happened, howerer, that I was arrare that a brother Officer, an old friend of mine, who is a thorough master of the German language, had most carefully compared the old and the new Drill Book, and had reduced that comparison to writing. On stating my difficulty to him, he, whilst declining to lecture himself, most generously placed the results of his labours at. my disposal, and those I am about to lay before jou. I, gentlemen,

1 Scc rol. Is, p. 710 et seq. 
am this aftemoon mercly the mechanism of the telephone: the utterances are those of "one who knows," but for the correctness I, with perfect confidence, hold myself responsible.

At the outset it is necessary to impress on your mints the marked distinction between the celition of the Drill Book which we nre con. sidering to-day and the celitions which preceded it. The carliest of the lattec bears the date 25th Scptember, 18.7. In the German Army there exists, side by side, a keen desire for progress on the one lamd, and on the other hand a clinging to the traditions of the past. Hence the edition of 1576 , neecssitated by the altered conditions of warfare, ns shown in the campaign of $1870-71$, was oflicially called $n$ "rejuint." It resembled a trec planted some thirty yenrs before, ou which had been grafted cuttings which would bear fruit suited to the military tastes nnd desires of later date. Conscquently, that edition was full of nuachronisms and modem ideas in strange juxtrposition, the former predominating, and the result beiner contradiction and consequent confusion. Practically, it contained two antagonistic and irreconeilable systems: one based on the war expericnec of bygone clays, the other on that of modern war. Of the many illustrations of the preclominnance of the old idens, one will suffiec, that of the reten. tion of the battalion directed by the battalion commander's nord of command, as the tactical unit. Reference to tho table of contents $\left(\Delta_{\text {plendix }}\right.$ To. 1) shows us that out of 105 pages dealing with the instruction and training of the individual soldier, the squad and company, the battalion and tho brigade, 59 pages or nearly half are deroted to the battalion.

'The retention of the battalion as the principal fighting unit was due to close formations being still regarded as fighting forrantious, and suitable for employment within reach of the enemy's fire. This becomes apparent from the uumerous erolutions in close formation laid down for the battalion, mang of which carry us back to the days of the Great Napoleon and the Peninsula, when, being admirnbly adapted to the tactical conditions of that period, they produced cscellent results.

'The much needed reform was initinted by the late Emporos, who did not, howerer, live to see the fruit of lis labours, and it was reserved to his son, the present Limperor, to complete the work by the issue of a book which is not a reprint, not cren an improred and revised edition; it is an entirely new crention, differing from its predecessors in many csscutial points and in most minor details. 'The statement of the Emperor's ricws regareling it iuus as follow:-

\section{"Ficrlin, 1st Scptcmler, 1888.}

" $I$ issue to the Arms these new Infuntry Drill Regulations, in grateful memory of His late Majesty, my fatlier, to whose initiatire their production is due. Their object is to produce a larger scope for war training, maintaining at the same time the discipline and ordej which have been lnaded down to us.

"The adrantage gained by the simplification of many of the formintions must on no acconnt be nullificd by ans one, either by rerbal 
or written additions to the Regulations for the purpose of obtaining increased outwrard uniformity, or for any other reasons.

"The freedom purposely conceded in the training and its applicetion should in no way be limited by any restrictions affecting the principles of these Regulations.

"I am firmly resolved to punish with clismissal anj contrarention of this my will.

"Any infringement of the provisions of Parts I and III will meet with screre censure, while nny misapprehension of Pait II should be rectified by means of instruction.

"To the War.Mrinistry."

(Signed) "WiLmeLs?.

It is interesting to notico the influence of the national spirit in these Regulations. Having cffectually shaken off the jobe of their enemies, the Germans are determined to get rid of the last trace of the French domination by purging their language of all germanized Frencle worls, thus carrying into effect the spirit of these German lines :-

Willsi du cin ccliter Deutscher scin

So sprichst du deine Sprache scin.

frecly rentered-

Wilt thou be 2 German true

Cleanso thy lauguage thro' and thro'.

There is even a marked progress in this respect, since the issue of the "Ficld Serrice Regulations, 1857."

'The following are some instances of this cliange:-

Old word.

Nicw rord.

Houncurs ......... Ehrenbezeugnngen.

Attacko............ Sturm.

Arertissement ...... Ankïndiguvg.

Engiagement, action.. Gefecht.

There is one word of forcign sound and curious applicntion still retained-i.e., "cliargiren "-in the words of comnand for firing.

Most striking also is the systematic and logical recasting the work has undergone. Its arrangement and tenching are as lucid, simple, and concise as those of the old book were complicated and diffuse. It moreorer numbers 57 pages less.

But if one thing nore than another sliows the completely new departure taken, it is the relative amount of space allotted to the drill and exercises of the sereral units in the book of 1876 and that of 18S8. $A$ brigado consists of 3 or 4 regiments, at regiment of 3 or 4 battalious, a battalion of 4 companies, a company of 3 ziige, the company being about 200 strong. Look now at the comprantive statement in the table:- 


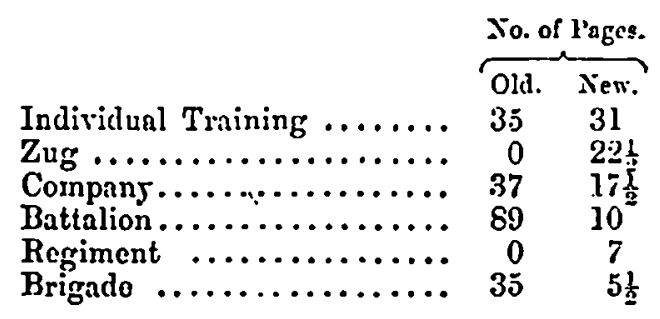

In itself the table is a recelation. Lcaving out of consideration the item individual training, which remains as before, we see that to the regiment a few pages aro giren, but the brigade retains but onesistl or one-serenth of -its former importance, the battalion only one-ninth. 'The reason of this is that hencefort $h_{1}$ the company is the only foghting tactical unit, and battalions, degiments, and brigades are regarded on the battle-field merely as concentrations and assemblages of the fighting units, the companies, whence they may be drawn for the purposes of the combat. Aud the reduction of space allotted in the book to the company, ns a whole, is more than made up by that given to its third, the zug, the lowest unit under an Officcr's command, and consisting of some sisty-four men which, litherto unrecognized, now springs into the first plnce.

Tho subjects connected with the forming, handling, and legitimate emplosment of the soldicr are divided into three parts :-I, The School; II, The Fight; 1II, Parades, \&c.

Out of a total of 169 pages, he is taught his lessons in "The School" in 80 pages, he is shown how practically to apply these lessons in

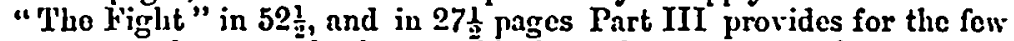
necessary show parades inseparable from the profession of arms.

Part I, "The School," is further subdivided iuto six sections, one for each link in the military chain, that may bo called apon to bear the stmin of war and act independently as a fighting mit. "Tlese are- $A$, "The Individual Soldier;" B, "The Zug;" C, "The Company;" D, "The Battalion ;" -lE, "The Regiment;" and F, "The Brigade."

The training of the individual soldier consists of instruction with and without the rifle, nnd as a unit of the fighting line. That of the zug and company, in which everything conuected with tho actual fighting is done, consists of instruction in close and extended formation.

The bey to Part II, "The Fight," lies in the number of pages respectively taken up by the three subdivisions composing it. "Tho total number deroted to "The Figlit" is $52 \frac{1}{2}$. Of these nearly three. yuarters are allotted to tho first subdivision dealing with "Genernl Principles." 'The second subdivision treats of the fight of the severnl tactical uuits, "The Company," "Ihe Battalion," "Tho Regiment," and "Tho Brigade," and is containcd in $13 \frac{1}{2}$ pages, each unit taking up about the same amount of space, the company having the largest

I Bg " unrecognized" is not encant that the zug itself clid not crist, but that as a fighting unit it was not recognized in the Drill boch.-L. 1 . H. 
number with 4 pages. The "Coucluding Remarks," not the least ro. markable part of the book, occups 3 pages, and form tho third aud last subdirision of Pnit II.

Even Part III, "Parades, \&c.," which bears a certain resemblance to its olsolete predecessor, has not been left untouclied by the hand of the reformer. It comprises foar parts: ( $\Lambda$ ) The Parade, (B) 'laking out and replacing the Colour, (C) Bugle Calls, (D) Brass and Reed Bands.

The Preface, tho threc Parts, and the three Appendices, No. 1 Bugle Calls (21), No. 2 Drum and Fifo Marches (12), No. 3 Sundry Calls on the Drums and Fifes (12), mako up the contents of the German Infantry Drill Regulations, 1888.

The object throughout these Regulations, which becomes particu. larly apparent in this part, is not to scek to provide for evely conceivablo contingeucs, thereby burdening the memory with num. berless details, but rather, thoroughly to farnish the mind with sound principles of general application. That is the clue to 36 pages of 56 ? being deroted to the general principles, in this most inportant part of the German soldier's instructions. There is no "Rule of Thumb" work here. Here wo find nothing but living principles, dednecd after much thought and labour from real modern war, not by the theorist, bat by the practical soldier who has proved his quality in ficld and cabinet, requiring the exerciso of rensouing poirers and application of judgment and common sense.

Drill and Training.-No better introdnction to the drill and training of the Gernan Army could be found, thau that giren in the book itself, from which tho following is an cxtract:-

1. 'The object of drill is to train and prepare both Offeers and men for war. All exercises should therefore be in conformity with war practice. The most important requirements of war are strict discipline and order, together with the utmost exertion of physical and mental powers. The derelopment of theso qualities to sucl a degree that they become n second nature to the men, is one of the principal objects of all esercises at drill and field practices.

It is only by simplicity that results are ensured in war. It therefore becomes mercly a question of mastering and practically applying a few simple formations. These, however, should be practised with strictness, and directed with certainty and precision. 'The provisions of the Regulations deal solely with normal formations, and are unconditionally binding in their spirit and letter, in peace as in war. All artificial claboration is prohibited.

2. All commanders of troops from tho Compans Commander upwards, are responsible that tho training of the units under their command is carried out in accordance with the Regulations, and they should therefore bo-restricted as little as possible in the choico of means. Their immediato superiors are in duty bound to interfere the moment they uotice ans crrors or shortcomings.

Each section of Part I- we shall now deal with in succession, commencing with Individual Instruction, and taking then the zag, the company, and then leading on to the brigade. 


\section{Pan:r I.-A. Indivilual Inslruction.}

The spirit of the training imparted is aptly described in the last clause of the concluding lemarks to Pnrt II: "The training of troops man properly bo considered as successfully acconiplished, when they are capable of performing what is required in war, and when no part of what has heen taught on the drill ground has to be laid aside on tho battlc-ficle."

In the old liegulations the instruction of the individnal soldier was scattered over Parts I, II, III, and IV; tho whole of it is now cmbraced in Part I, Section $A$. Every section and subsection that requires it, is: preceled by pithy "General Remarks." These shall be giren in full.

$\S 1$. "The carcful and strict individual instruction which should be conducted concurrently with the physical training prescribed in the Gymnastic Regulatious, is the foundation of tho soldier's training as a whole. 'The requisito combined action of numbers can only be attained by the thorough instruction of the indiridual. 'The faulty and incomplete instruction of a recruit, as a rule, affects him prejndicially in the performance of his daties, during his entire service. Faults which are allowed to crecp in daring tho initinl stages of the instruction, aro rarcly completely oradicated. It is likewisc impossible to renedy- defective instructions by means of combined practices."

l'bese words, together with the amount of space allotted to this: subject, give us an inkling of the importance attached to this first moulding of the young soldier, ${ }^{1}$ and a further cxamiuation will convince us as to the soundness and practical character of the instruction imparted.

Appendix No. 2 shows as what has becn abolished in this portion.

With $\mathrm{n}$ riew to lesscning fatigue on the warch, the command "Ohne T'ritt," or "Out of step," is given. The men are thereby reliered from the necessity of nccurately keeping the Regulation step. The normal distance (from back to breast) betwecn ravks is then increased from 0.61 to $0.50 \mathrm{~m}$. ( $25-31 \frac{1}{2}$ inches). The men, however, maintain the regulated pace, an orderly bearing, and their proper places in the ranks. On tho command "T'ritt gefasst," or "In step," the ordiuary step and distance is resumed. In marching off "out of step" the command is "Ohne Tritt-Marsch," or "Out of stepMarch."

With regard to instruction in "Firing," the most important portions of the Mlusketry Regulations bearing upon the effectivo use of tho rifle in action, with which it is essential tho soldier sliould be perfectly fnmiliar, are inserted bodily in the new Regulations.

In peace-time, bayonets aro no longer fixed, and it is considered sufficiont that the soldicr shonld bo instructed in "fining" and "unfixing;" the object being cloubtless to sare the rifle. On all occasions, howerer, in which bayonets would actually bo fired in battle, the order to "fix," either by command or bugle-call, should invariably be giren, without its being carricel out by tho men.

The most important part of the training, being that for the fight in

1 Sce "The Training of the German Recruit," in No. 1.17 of the Journal,-ED. 
extended order, let us hear what the "Genemal Rewarks" liare to tell us as to the methods adopted:- $\$ 61-66$. "In order to render the recruit fawiline with the rudinents of the independent use of the ride, it should bo placel in his hands a few days nfter he joins and before being instructed in the manipulation. 'The instruction on the sereral parts of the rifle and their combined rorking, should go hand in hand with that in londing, the firing positions, and iiming.

"After the soldicr has macle some propress in londing. the firing positions, and in carrying the rille at the slope, and after he has obtained a clear grasp of the first principles of subordination, the instraction in cxtended order fighting should be proceeded with.

"For this purpose, he should be mado to acquiro the rudimentary notions of the mature of fighting in extencled order, by affording line opportunitics of obserriner tho working of small parties of older. soldiers, orer casily accessible ground.

" His zeal for, and powers of understanding the lighest objects of his calling, shonld then bo stimulated and sustaincd, by making him take an active part in representations of the simplest phases of the fight.

"His dutics in the attack and the defence, and the manner of turning tho mature of the ground to nccount in increasing his own fire action and reducing that of the enems, should be tunght him by menns of an opposing forec, at short ranyes to commeuce with.

"These excreises can be carried out at all times of the year, on the ficld-practice ranges and on the drill ground. After the recrnit. has served tro or three weeks, he should be taken out for this purposo into the conntry at least twice a week. This is a decieledly beneficial chnnge daring the period of formal cluill instruction, which can best be furthered b5 the recruit bringing with him a certain insight into the practical application of the extended order formations practised on the drill ground.

"In regulating and directing these field practices, the difference of the demands made npon lim in the formal excreises principally connected with close formations, and those connected witil extended formations, should be explained to him.

"Plents of timo should be allowed for the carcful and thorough training of the solelier, as it cannot be effected if the courso of instraction is unduly hurried orer and repetition is to be aroided.

"It will soon bccome apparent which men are particularly smart. The greatest attention slould be deroted to the training of these men with a vicw to appointing then zug and section leaters in dae course. Awkwarl men nust not be permitted to returl the progressire instruction of the class they belong to."

It is laid down, that the men should bo practised in surmounting obstacles of all descriptions, and be thorouglyly trained in taking adrantige of corer. 'Thes should, howerer, be taught that in the majority of cases the straight was is the best way, and that a considerations as to corer should gire was to those regarding fro action.

Theoretical masketry instruction and judging distances should go 
hand in hand with this part of the instruction, followed by blank aud ball firing.

\section{Pirs I.-B. The Zug.}

Now, for the first time, the zag is given its legitimate place in the Duill Regulations. It is recognized as a real fighting unit, and assumes its dutics and responsibilitics. On the completion of the individanl training of tho recruit, say tho Gencral Rernarks, $\$ 81$, ho is formed up with sereral others in line, files, sections, and is prepared, by being exercised in züge, for taking his place in the company, in close as well as extended formation.. In the zug as necll as in all larger units, the same certainty and order should prevail, whicherer rank may bo in front or whicherer flank is leading. Tho zug should nlso be nble to excente all regulation morements in perfect silence even when in an unusual order, witl files intermixed (termed " uurangirtes excrziren " or drillingr in " mixed order"), "in step," and " out of step."

'line zug, formerly the half (in close formation) is now the third of a company, and is commanded by subaltern Oficers, called zug leaders.

It is now formed in two mnks instcad of thrce, both sized from the right, the tallest man of cach filc in front. The lateral space occupied by the soldier in the ranks is not laid down. It is merely stated that he should in all cases, cren on parade, hare a light touch of the elbow with his riglit and left-hand men. This will cnable him to fire and execute all lis novements in the ranks without constraint.

$\Lambda$ zug of sixtcen files and orer is divided into balf-zügc, and the hnlf-zïge again into sections, which in extended order nro called groups. $\Lambda$ zug of fifteen files and nader is not subdirided into linif-ziige. In either case the section slould not consist of more than six or less than four files. The sections aro numbercd from the right of the zug. The zug leador stands in front of his zug when working alone. $\Lambda$ flank non-commissioned offeer is placed on cither flank of the front rank, the remaining non-commissioned officers two paces from the second rank, standing in rear of the last file of the section they rommand in extencled formation.

The crolntions performed by the zag in close formation are shown in $\Lambda$ ppendix 4.

The dressing is alwags by the right (unless specially ordered otherwisc). 'The men are practised to form up rapidly on points (the flant non-commissioned officers) or on files. $A$ good advance of the zug in line over considerable distance, is considered the fondation of all movements in close formation. In file marching, the front rank directs. Mnrching in file is nsed for short distances only, as it entails great cxcrtion, haring to be esccuted "in step" so as to retain the proper distances.

There are two new terms, "Ziehen," to denote the dingonal march, and "Hakenschwenkung," a change of direction in column, each component part whecling in succession on reaching a gircn spot. 


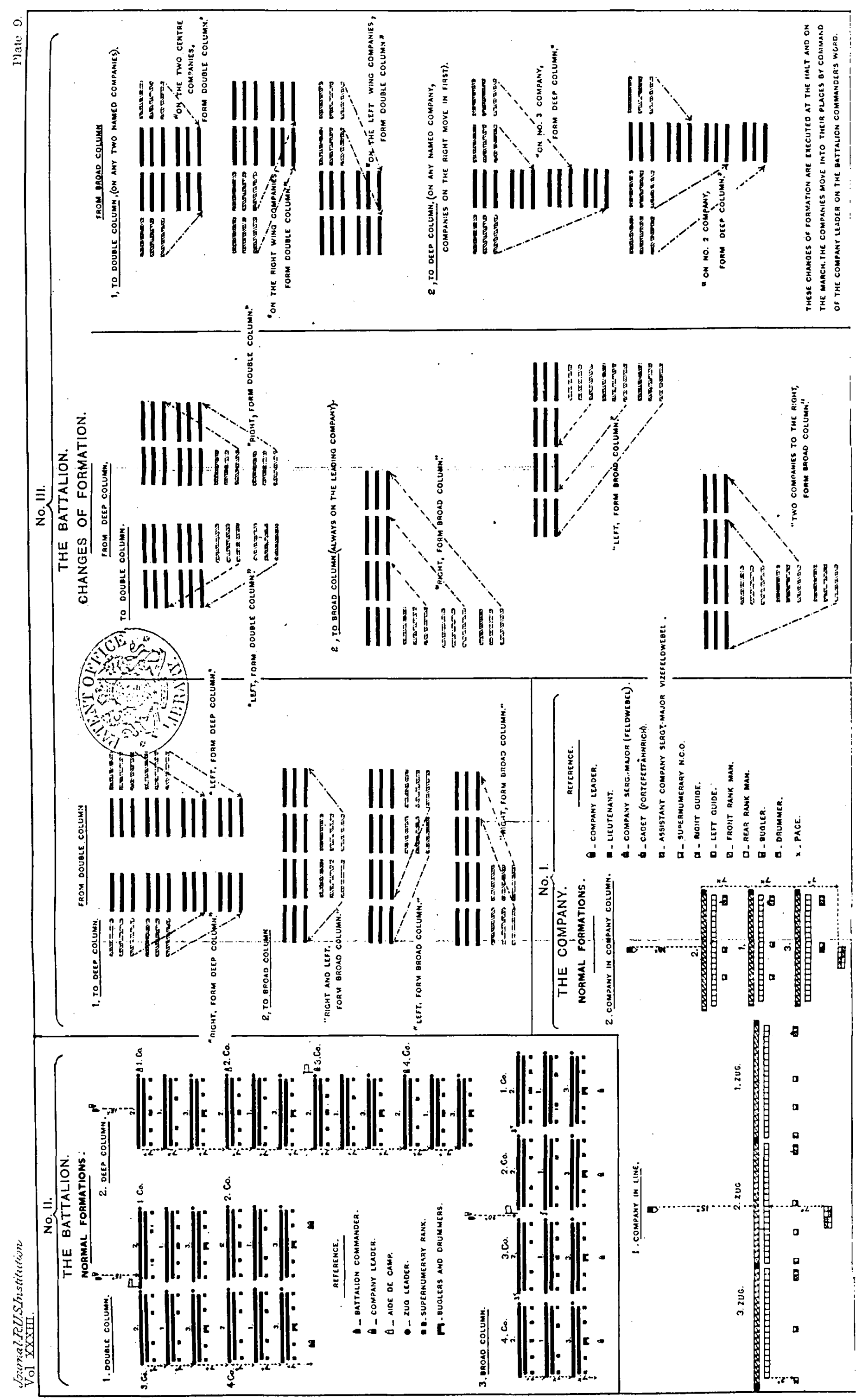


The Zug in Extended Formation.-(General Remarks.) "In training men for fighting or extended order, it is likewise not expedient to pass suddenly from individual instruction to that of the sug. Practices in files aud groups should mather precede it. By them the soldier is first taught his functions as a unit in the fighting line, in which be has not only to respond to the leading of his group leader bat also to consider the nen on his right and left in his movemonts.

"Whereas a single soldier moving freels over the country will bo able to find plents of corer and is permitted to do so, the zug and still moro the larger units, are only able to arail themselves of this adrantige under certain circumstances, which it is tho daty of the leaders to make tho most of. Considerations regarding cover should on no account interfere with the uniform movement of the whole. For this reason alone the successive and connected morements of fighting lines form a verg important subject in tho training.

"Iho difficulty of execution increases with the extension and density of the liuc. At the commencement these exercises should be carried out with shorter lines at grenter interrals of extension."

Movements in extended formation are performed, as a rule, at the ordinary pace-only exceptionally at the double. In the adrance by rushes, tho space corcred each time should rarely excecd $80 \mathrm{~m}$. (87 gards).

The morements of a $\mathrm{zag}$ in extended formation are:-

1st. Adrance and retirement of the zug or portion of it.

2ud. Moving to a lank by the diagonal march.

3rd. Chango of direction by the indication of a new point to march on.

Mlorements to a fank, in file, should be aroided. A rigid adherence to dressing and intervals should not be required.

"The men are to bo distinctly instracted to close up or open out for tho parpose of arailing themselves of corer."

"The only thing to be considered with regard to clressing is, that the several portions of the fighting line do not interfero with one another in their movements and fre."-(Part II, 26, 27.)

The extension may be at the halt or on the more. When extending, the rear rank men more up on the right of their front rank men. The interral of extension, unless specially ordered otherwise by the 2.0 leader, is from one to two paces. Units in extended order march by their contre.

An extension, during a morement to tho rear, is performed at the halt and facing the enemy.

Each group is commanded by $\Omega$ non-commissioned ofticer. Tho zug and group leaders place themselves in front of their respectire clirges, and, if possible, one or more non-commissioned oflicers are kept in rear of each zug, to superintend its movements.

Fire is only opened by a fighting line, when in position. It is only in cxceptional cases that firing is allowed on the more. The instructions as to fire action, firc leading, fire discipline, the different kinds

rOL. XSXIII. $2 P$ 
of :fire, and the observation of fire effect; aro all- cxtracts from the Musketry Regulations.

Sights should be adjusted with the greatest care during all practices.

'The extended zug, when closed, fornis up in line. If the zag leader continues to advance, the elosing is carried out on the more.

The cliange of front of extended lines, by wheeling or on files, is abolished, aud a cliango of direction is effected by inclicating a fresh point of direction. The reliering of a fighting line is no longer pro. rided for.

\section{Part I.-C. The Company.}

Instead of 37 pages in the superseded Regulations, the Instructions on Company Drill and Fighting only take up 17t pages in the new book. Its independenco is $n$ trainiug and fighting unit has, howerer, been largely incrensed. The mefnce says, in para. 3: "The masteriug of the netual drill should be accomplished in the company." 'The simplification this drill has undergone, has been most thorough and practical.

The company is composed of threo rugge, and cach zur into two half-züge. The zügc nnd half-zügo aro numbercd from the right of tho compans. $\Lambda$ footnote states that it is advantageous if this sub. division of the company into zïgc, half-zïge, and sections is adopted and maintained, for parposes of interior economs, aud if the men of a company are as much as possible of the samo size.

As to its capabilitics, the "General Remarks" sny (\$ 143): "The compans should bo so thoronglily trained, that it mas remain under the control of the company leader under all circumstances, and that by paying proper attention to his orders, it mas bo ablo to carry out cren what it may not bave practised preriously." "The two normal closo formations of the company arc given in Dingram No. I. (Sce Plate.)

The distribution of the Olficers to the züge, is left to the Compans Commander. The morements of a company in close formation are of the simplest description, as will be seen by referring to Appendix 4 .

The distanco between zügo in company column, and betreen companies in battalion colamn is alwajs seven paces. ${ }^{1}$ In half-zug column, the full distance of scren paces should be gained when moring outside the spliere of the enemy's fire. When required to reduce the depth of the column, it is redaced to four pices.

All changes of formation into and out of company colnmu are cxecuted "out of step."

The dressing is alwajs by the right, unless otherwise ordered. When two zügo are marching in line, the dressing is by the centro zuer leader.

In dressing up or taking up an alignment, the points giren are two zucg leaders and the outer fiank Officer.

Company Square.-This company square is formed at the halt. The lerding zug is halted, tho next zug wheels ontwards and forms tho

1 Ircais rad from frcut rank to frost raus. 
side faces, the 3rdiZng closes ap and forms the rcar face. It is tho last vestigro in European tactics of a formation, which tho Germans consider so woll calculated to delay and restrict tho development of the highest firo action at the most criticnl moment, and to co:operate with the cncms's cavalry in its endeavour to provide a good target for its artillery.

-Tho Regulations sas: "Complete regalarity in the formation of square is not to be required, but prompt readiness to open fire in any direclion must be insistcd on." 'This condition of promptness in forming square and opening fre is moro casily attainable in this comparativels small unit, which, morcorcr, forms a relatirely small target for guns.

The ordinnry movements in square are provided for. The occasions on which the squaro may be used aro laid down in para. 50, thus: " T'ho adoption of the square formation can only be considered suitable, when required by special circumstances, such as when tho troops have expended their ammunition; when thes havo been sererely sliaken by heary losses during the fight; or when compelled to retreat orer open ground, in the piesenco of threatening caralry, superior in numbers. Infantry engaged with caralry should benr in mind, in all other cases, that the latter are justified in counting it as an adrantage gained, is soou as thes suececd in compelling them to discontinuo their norements and to assumo formations which will interfere with the derelopment of the most effectire fire-action."

The firing of a company in closo formation may bo delirered in line, company column, and in square. Volless are delivered by companies or by zügc. The zug lenders place themselres in rear of their respective züge, and call out their numbers before ordering them to ine. A company column at the halt may close np, so as to firc four deep. In square, rolless should, as a rale, be used, the side of the square required to fire being named.

Bayonet Charge.-The instructions commence with these words: "Should tho company be requircd to charge in close formation," as if to indicate the unlibeliliood of snch a procending. The company comes to tho chargo and breaks into the "Storm March." $\Lambda$ t $n$ distance, dependent ou the circumstance of each case, the company is ordered to donble and cheer. Tho drums beat the "Storm Miarch" (tho fifes do not play). After securing the position, the leading züge make ready and wait for the command to open fire on the retreating foc. In an unsuccessful attack, the troops in close formation and the forliting line retire simultaneously, the former in the strictust order and " in step."

The Company in Extended Formation.-Tho training and morements of a feghtirig line are fully dealt with in the zug instraction. Thoso for tho compans are limited to (1) Lstension, (2) Reinforcing, (3) Support, (4) Asscmbly, and that only brielly.

Unless otherwise ordered, cntiro züge moro ont on the command "cxtend." In company column tho leading zug, in line any uamed zug. The remainder of the company forms the sapport in line or column, and does not move off until the fighting line has gained the requisite 
distance. $\Lambda \mathbf{n}$ interval of seven paces is maintained between züge in the fighting line.

The fighting line is reinforced by command of the company leader, cither by the insertion of fresh zügo into the line itself, or by pro. longing it. In tho former case, the zug ordered to reinforco extends at once, and wakes direct for the interval between the züge or any existing space in the zügn already extended. An intermixing of zügo is here candidly acknowledged as unaroidable, nad, as far as possible to mitigato this evil, it is dirceted that the company should bo practised in assuming fresh subdivisions, tho zag and group leaders dividing the line betreen them.

How different from the unbending spirit of tho old Regulations! These say" (pago 68, $\S 39$, Chap. VIII) : "For tho sake of preserving unity of command, in rcinforcing and reducing tho skirmishing line, the original züge and sections should not, where possible, be separated, they should not, in any case, however, be interuixed." The same principle in other words is enforced on page 143, $\$ 103$, and page 187, second paragraph.

T7e Support.- " The portion of the company remaining in close formation serves for the extension of the fighting front, the support of the firing line and the protection of its flanks." These considera. tions regulate its position.

Its distance from tho fighting line depends upon circumstances. No fixed ralo can bo given. 'The main consideration is tho timely support of the fighting line.

For practices in which the nature of the ground is not taken into account, the distance should be about 150 paces.

The support, formed in column or line, marches without keeping step, and conforms to the movements of the fighting linc. When under the cnemy's cffective fre, it marches " in step," and crery change of formation is aroided. At the halt, the support lies or bnecls down.

On the company leader's command to assemble, the züge, haring rallicd on tho zug leaders, assemble in compnny column in rear of that portion of the company still in close formation. The company is to be practised to assemble in company column, line, and column of sections with silence and rapidity at ans appointed place.

The principal alterations are shorn in Appendices 2 and 3.

\section{PART I.-D. The Battalion.}

The 89 pages deroted to the battalion in the Regulations of 1876 aro reduced to 10 . This includes the instructions in Part II for procedure in actiou. This reduction is duo to sereral causes : 1st. 'Tho individual instruction and that of the company are relegated to their proper place. 2nd. The relatire position of the battalion in the chain of military units has been modified considembly. It is, of course, still one of the most important "units of command," bnt its character as a "fighting mnit" has been changed. The former dutics in action of the battalion as a whole, now devolre on the four companics of 
which it is composed. Their actunl handling when in the fighting line; is taken out of the hands of the Battalion Commander, and rests entirely with the coinpany leaders. 'This is expressly stated in tho last threc lines of this section, page $82, \S 219$ : "I'he direction of the fight in tho extended fighting line, rests with the companies." The Battalion Commander's duties aro very clearly defincd, and he has ample scope given him to make his influence advantageously felt in action, without interfering with those who hare actually to do the work.

The Preface says: "The battalion is the training school for the fight. The whole system of iufantry fighting is based on the co-operation of the sereral companies with ono another in the various phases of the fight:" nud again, "Battalion drill, now ouly conbraces close formations."

The Battalion Commnader now tells his fony company leaders what ho requires to be 'done, giving them each their share of the tash, but he refraius from telling them how to do it. In fact, if that were Labitually necessary in any particular case, tho Officer concerned would not loner bo allowed to remain in the German $\Lambda \mathrm{rm} 5$. Theso are the "Gencral leemarks," § 197 : "The battalion, composed of four: company columus must be able to executo the simple formations required in war on the conmand of the Battalion Commander, under all circumstances; with regularity and certainty."

The Battalion Commander delivers either both the cautionarg and exccutire words of command or only tho former. Cautionary and crecutive, when simultaneous execution by the cormpanies formed up in either of the three normal battalion formations is required. In all other cases, the llattalion Commander delirers ouls the cantionary cominand.

The change from ono formation to another is executed, as a rule, at "the slope." If not otherwise ordered, the companies at onco " order," "Stand at case," and take up their dressing on reaching their places.

On the drill ground, the morements in the norwal formations and the change from the ono to the other are executed in step. The deployment for the fight takes place either with or without keeping step at the Battalion Commander's discretion. All other company morczuents are executed out of step. When under the enemy's effectiro firo the marching is to bo in step.

The natural consequence of the battalion baring practically dropped its charncter as a nuit in tho fighting line, is that battalion drill has been completely rerolutionized. Battalion fighting formations no longer exist. Tho formations of a battalion are simply close formations iutended for the convenient assembling of large wuasses of troops. Appendis 5 contains a complete list of battalion movements.

Companies in battalion columns are invariably formed in company columus. The battalion is drawn up in mass or line of company columns necording to the space arailable and the object in view. The order of tho compauies is inmaterial. They more into column by command of the company leaders, by tho shortest way.

Dressing and Cocering. - $\Lambda$ t the lialt, the dressing is by the right; 
on the more, by the colour, in broad and double colunn; and by the right in deep column.

In broad nal double column the "Points of formation" are tho colour, the zug lealers of the lending units, and the left flink noncomnissioned officcrs. In decp columu, the zug lenders and the left flank non-commissioned officers.

In brond colunn, files must maintain their uwn corcring; in double columu, the zug leaders and left flank non-commissioned oflicers look to tho corering. In decp column, the eug lenders corcr.

Motions with the Rifle. - The motions with tho rifle and londing are not prnctised when the companies are formed up in battalion columns, crecpt when it becomes necessiry for the sake of unifornity.

Deployment of the Battulion for Action.-The manucr in which the companies cnter into action may vary considerably. Generally the companics will be inscrted into the fightinte line as required, the remainder bciug kept in hand by the Batialion. Commander. But circumstances maj require the simultancous deployment' of all the companics fron tho very commencement. Such deployments to the front occupy the shortest tine when performed at the halt. The order for tho deploynent should indicate the comprny of formation as well as tho intervals and tho relative positions of tho severnl companies. As a rulo grenter depth than breadth will bo given to the original cleployment, the fighting line will be reinforced gradually, and at least ono company will bo retaincd in rescrve.

The morements of a battalion when depleyed for action nue recralated by indicating a common point of direction. A company of dircetion should ouly be named, when there is no point of clirection. A change of dircetion is effected, by indicating is fresh point to march on.

If a chango of front is to bo effected, tho new froat will bo pointed out, and the compauirs whecl up independently into the requirec dircction. The relative position of the companics is thercbs clnaged. 'T'his nay bo regulated by further orders.

'The companies are reassembled in battalion, as a rulc, on the march, otherwise at the halt, in the shortest way, on a named compaus, in one of the normal formatiuns suitcd to the occnsion.

Tho adoption of fixed formations to inect given cescs, is prolibited.

$\Lambda$ complete list of the chinges made in battalion drill is giren in Appendices 2 and 3.

Tho principal formations, sic., laid aside are-

1. Battalion line and linear tactics.

2. Columns of rarious distances.

3. Battalion fighting formations.

4. Attack in closo formation.

5. Battalion squarce.

P.нi: I.-E. The Regiment.

The old Regulations contain no instructions for the reginental "uuit of command." In the new Regulations, it is given its proper place, nud takes up seren pages. 
To quote the preface, "Regimental drill embraces merely formations of assembly," and "The uniform education necessars for undertaking the duties connected with the training and leading of troops is jmparted in the reginent. Regimental exercises aro a preparation for the duties of higher commands."

\section{General Remarlis.}

$A$ battalion should be able to perform all the regulation baltalion norenents with precision, not only when alono but nlso in combination with other battalions. 'This is attained, by practising the regular and prompt forming up from column of march, into assembly or fighting formation, as well as those movements which are carricd out irith larger units. It should, however, be borne in mind, that uniform movements in closo formation but rarely occur in was, and only adnit of uniform execution within tho battalion. Thes shonld therefore be restricted to the simplest description.

The Recrimental Commander only gires cautionars words of command or orders, on which the Battalion. Commanders delirer the necessary cotnmands.

Assmuly Formations of the Regiment.-Battalions are as a rolo formed up in one or more lines of doublo columns.

If the regiment is composed of threc hattalions, and is formed up in two lines, one battalion is placed in the centre of the interval, either in tront or in rear of the two others. If composed of four battnlions, the battalions in sceond line corer those of the first. In the normal formation, battalions are placed in numcrical order in cach line, but any oucler is admissible. The interrals are twenty and tho distance thirty paces (clcar space). Whencrer required for any special object, the battalions, in ans of tho three normal column formations, mas be drawn up in auy manner desired.

Horements in Assembly Formation.-Theso cousist of simple morements to the front and rear, wheels and marchine to a flank, and will be crecuted in accordance with the instructions laid down for the battalion.

For the initial morements, a battalion of direction will be naned. Tho leading zllgo of all companies abreast should retain their dressing; this is not required in the case of the suceeding zïge.

When the movement is carricd ont "in step," cach battalion keeps its own step.

Changes of front (not grenter than one-cighth) are cnrried out on a named hattalion, which after wheeling up, advances column depth and halts. The remainder moro into position by the shortest way. If tho reginent is formed in tro lines, tho first advances the depth of both liues after whecling, and the remainder take post in the shortest was.

Deployment for Action of the Reginent.-The fundaunental consideration in the deployment of a regiment for action is the retention of the decp formation. The mnnner of deploying may rary considerably.

Tho battalions retained in closed formations are placed in cchelon 
in rear of ono or both flanks. The narrower the original frout taken up, the furtlier away from the flanks should the units in echelon be posted, for tho propose of commauding the whole extent of front required. 'The prolongation of the fighting front, is effected by meaus of fresh battalions. In the advance, the deplogment is carricd out on the lending and in retiring on the rear battalion. When the deployment takes place from column of march, the sereral battalions avail themselres of a suitable opportunity for closing up into column formation previous to deploying.

If the regiment is in assembly formation, the deplogment may bo carried out before advancing. In all cases tho battalion on which the deployment is to be made must be named. When the deplojment is mnde on the more, the battalions forming the rear lines balt so as to gain their proper distance and place.

The distances depend apon circumstances. The intervals between battalions in first line, depend upon tho task imposed, the object to bo attained, and the nature of tho countrs. In the original deployment the interrals should be ordered. The deployments are carricd ont, in or out of step, by the shortest way.

The movements of the recriments when deplojed, are dirceted by giving the sereral battalions points to march on. $\Lambda$ new front can generally only be taken up, by the deployment of tho units echeloned in rear, in the required direction. If necessars, the original first line forms up in eclelon in rear of tho new front.

A nnit of dircetion should not be named; on the other hand, whenever expedient, troops shonld be ordered to keep up connection with the centre or a flank.

When on the more, the regiment is re-formed, as $n$ rule, in the direction of march, otherwise on a given line, in the requircd formation, on a specified battalion, by the sliortest way.

'The deplogment of the company column, rests with the battalions.

\section{Part I.-W. The Irigade.}

The fate of the battalion, has orertaben the brigade ercn to a greater degree. The preface states that "Brigade Drill embraces mercls formations of Assembly" and "Brigade excreises, more particularly, are a preparation for the duties of higher commands." As a fighting unit it has been disestablished, and as a mecessary consequence the space allotted to its drill and other instructions lins shrank down from 35 to $5 \frac{1}{2}$ pages. Nevertheless, the dutics that are still left to it are of great importance, and can only be efliciently performed by an educated practical soidier.

The "Gencral Remarts" state briefly that "The instructions for the regiment are applicable to the brigade. I'be cautionary commands of the Brigade Commander are passed on by the Regimental Commanders."

The brigade is formed up either in wings or lines. In wings the regiments formed in mass of kattalions, are placed side by side. In 
lines, the junior battalion is in frent line when in the normal formation. But any other order is admissible.

When tho several lines are composed of the same number of battalions, these cover cach other, otherwise tho battalions in second line are placed in rear of the interrals.

The distance betwcen lines and the interrals, is tho same as with the regiment.

The positions of single battalions and battcries attacled to the brigado are specinlly indicated.

The movements of the brigade in assembly formations, are to be restricted to tho simplest description, and correspond geverally to those of the regiment.

\section{The Deployment of a Erigade for Action.}

The issue of instructions for the execution of independent tasks in action to the subordinate units of command (regiments and independeut battalions) witlin its fighting front, forms the basis of the deplogment of tho brigade for action. Tho execution, howerer, depends upon circumstances.

If the Brigade Commander is able to indicate to the screral regiments, simultaueousls, points of direction situated closu together, the circamstances aro the most favourable and normal for the deploywent.

If only one reginent has been originally deployed for action, tho most saitable place for the deployment or assembly of the remaining units of command, is in cchelon in rear of ovo or both flanks.

All the movements of the brigade should bo regulated by giving points to the several units of command to marcl on. A brigade composed of two regiments only; nuay at once place ono battalion in reserve.

Everything else is carried out in accordance with the instractions for the deployment of regiments for action.

The deployment of the battalion for action rests with the regiment.

So far we hare dealt with the School. Now comes Part II, The Fight, three quarter's of which, it must be remembered, deal, as has been already stated, with general principles.

The principles contained in this part, once branded by mans, and still by some in tho military world of Europe, as the fanciful notions of theorists, now bear the official cudorsement of the most experienced, practicil, and enlightencd soldiers of the agc.

'To be fulls appreciated, crery word of l'art II should bo carefully read, marked, learnt, and inwardly digested. It is so conciso as scarcely to aduit of further condensation. Want of spucc, howerer, compels us to deal with it in a more or less summary fishion. Those who wisls to study it fully, I would refer to the translation of it by Captain W. H. Sawyer, Rogal Lancaster Regiment, I3rigndc-Major, lst Infantry Brigade, Aldershot, nud published by IIessr's. Stanford f Cockspur. Strcet. This translation I hare most carcfully comparcd 
with the original, and I can bear my lumble testimony to the closeness of the two. It is an excellent shillingsworth.

Thesc instructious for guidance in training and in battle, qualify Officers and men for the iutelligent and cffectire application in the field, of the lessons they hare learnt in peace-time, by giring theun sound principles to rork on.

We unust turn to para. 125 to ascertain the real scope of this part of the Regulations: "The more advanced practices with mixcd units and even tactical exercises in which tho presence of the various aruns is supposed, produce tactical situations and call forth decisions which are far bejond the scopo of these Regulations. They in no way eshaust tactical instruction, but confino themselves to dealing with fundamental rules. The troops will, howerer, be able, eren in action, to cope with any possible task, if they hare, by practice, mastered the rules contained in these liegulations."

Formations only Normal.- Part II refers to the formations laid down in Part I, thus ( $\$ 1)$ : "The thorongh mastery of the simplo formetions laid down in Part I forms the basis for a careful and uniform tmining of infantry. 'This training would, howerer, fail in its main object, were it not to go hand-in-hand with an intelligent application of these formations to the requirements of war." $\$ 4$. "The normal formations should be giren np without hesitation whenerer the rnrying circumstances require it." $\$ 5$. "The formetion selected sliould bo sach as would be ordered in war to ensure the highest fire action, and which would be permitted for the purpose of reducing the effect of the enems's furo. Whenerer theso two conditions aro fulfilled the practice is in conformity with the reqnirements of war." $\$ 121$. "It should be borne in mind that the formations and principles laid down only deal with the simplest cases, and, owing to change of circamstances, will frequently experience modificatiou when applied in tho presence of the enemy," and "adberence to ccrtain formations should never be allowed to divert attention from essentials."

Thesc few extracts show us clearly what careful precautions hare been taken to prevent the action of the "executive" from being in any was hampered by the nisdirected efforts of mischicrous formalism.

Spheres of Action of Commanders.-The chance of a breakdown of the military machine in the strain of war and stress of battle, has been reduced to a mininum by a judicious subdivision of labour and responsibility amongst all ranks. Tho exact duties and spheres of action of ench leader liare becn carefally defined. The subordinates are thus left alone to do their own work in tho fighting linc, whilst the higher commanders, reliered from minor details, are able to turn their minds to the larger problems of strategy, dec, a wrong solntion of which cannot be compensated for by ans amount of hard fighting. The following concluding paragraphs to the Brigade, Regimental, and Battalion Instructious in Part I are significant and of very cousiderable importance.

F. Brigade. $\left\{\begin{array}{c}\text { "The deployment of the batto } \\ \text { in the hands of the regiment." }\end{array}\right.$ 
\$ 225 "The deployment of the company columns for action E. Regimont. \{rests with tho battalion."

$\$=19 \quad$ "The direction of the fight in the fighting line rests D. Battalion. \{ with the companics."

They aro very fally borne ont by the following paragraphs of Part II :-

Commencing with the lowest ranks, we find the possibility of the private soldier having ( $\$ 61$ ) to assume the leadership of his comrades in action, after all his superiors are inca pacitated, taken into considerntion, and provided for by tho special triining ho now rrecives. $\$ 21$. "It is the Officer's duty to derelop the judgment and self-relinnce of the soldier;" and, "He should crer be reads to take rapid, wellconsidered, independent action."

The Group Leader.- $\$ 56$. "He assists the zag leader, and is responsible within his orn sphero for the placing of the men, for tho adjustnent of the sights, the proper handling of the rifle, the consumption of ammunition, and tho replenishing of the magazine."

The Zug Leader. - $\$ 55$. "Ho should tako up such a position as will enable him to superintend the fire action of his men. Ho arranges the disposition of his zag in tho spaco allotted to it, and decides on which objects the fire is to be directed, either in accordance with his instructions or on his own responsibility. Ho follows closely, the measures taken by tho enemy and endenvours, nccording to his ability, to co-operate with the adjoining züge in the fighting line. He endearours to ascertain, prerious to a farther adrance, how the fighting line, or portions of it, could bo brought up closer to the enems; whether or in what manner a tarning movement could bo initiated; or whether ndrantage could be taken of any exposed point in tho enemy's line. The zug leader in the fighting line will bo best able to obserro any opportunity of seizing an adrantageons position, or of gaining an advantage orer the enems. He should then make np his mind how far ho shoald, on his own responsibility, tarn such adrantage to account."

The Company Leader. - $\$ 95$. " He should retain control of his company daring tho fight. Ho conress his intentions to the zug leaders in tho form of concise and clear orders, and takes up such a position as will enablo him to direct his company. Ho arranges for the supply and distribntion of the ammunition brought ap from tho rear, with all the means at his disposal on the battle-field."

The Battalion Commander:- $-\$ 96$. "Tho method adopted by the Commander in working his battalion in action, is to assign tasks to the several companies. Direct interference with the züge of individual companies is only permitted when erident misunderstandings or mistakes threaten to divert the courso of the action into improper directions. It is tho daty of tho Battalion Commander, at the rommencement of the fight, to impart his orders briefl 5 , clearly, and with precision to each ono of the company leaders -if possiblo in the preseuce of them all-learing the manner of execution to them. $\mathrm{He}$ should be gaided by this principlo throaghont the course of the action. His endeavour should bo to maintain the co-operation of the 
several companies with ono another during the fight." $\$ 101$. "It is with regard to the troops placed in rear of the fighting live, either in echelon or in rear of the centre, that the Battalion Corn. mander selects his own position, which is only quito exceptionally in the forcmost line, nearly always with the troops in rear, but in any case in some place whence he can exercise supervision over lis battalion in action. He will frequently only be able to affect tho fire action of the companies, by directing the fresh supplies of ammunition to those points in the fighting line, where it maj be most necded."

The Regimental Commander:- $\$ 103$. "Ho appoints separate tasks to the sereral battalions, leaving them perfect freedom as to the manner of exccution. Interference with the conduct of individual companies should be restricted to rare cxceptional cases, and is only justifiable when the action of subordinate bodies threatens serionsly to interfero with the execution of the Commander's general intentions, and there is no time to issue the necessary orders through the proper channel." $\S 109$. "For the due execution of the tasks imposed upon him, the liegimental Commander should take up a properly selected position. At the commencement this will be in front. His presence is principally required there in the case of an encounter between troops in motion. During the fight, he can generally direct his troops to the best adrantage from the ricinity of the troops echcloned in rear, that is, whence lie can exercise the best superrision over the employsnent of his regiment. Shonld his regiment be fighting in brigrade, ho should sclect such a position as will enable bim to keep up communication with the Brigade Commander."

The Brigade Commander.- $\$ 112$. "The rale should be adhered to nuder all circumstances, that each regiment is to be allotted its own separate task, and that the Brigade Commander should confine bimself to delirering his order's to regiments onls." $\$ 114$. "The selection of tho Brignde Commander's position is of great importance and should be clianged as rarely as possible. The commencement of an action should find him at the head of the brigade; for ucither reports, nor information, nor maps can take the place of a personal inspection of the enemy's position, that of the neighbouring troops, or of the ground. In that position he is hest able effectually to dircet the initial deployment, on which the course of the action so greatly depends.

"It likerise enables him to seize ndrantages orer the enemy, by arriving at timely decisions, to ensuro his troops taking the shortest routes, to direct their action into proper channcls, and finally to prerent any irregular action on the part of the Commander of the adranced troops. During the action, bowever, the Commander remains sufficicutly in rear to enable lim to exercise supervision orer the several parts of his brigade. 'This will genernlly be in the ricinity of the troops he has retained at his disposal. It is only from there that be can still control the course of the fight. He delirers his orders, as a rule, to his immedinte suburdiuates. Should circunstauces compel hin to deriate from this rule and to give in- 
diridual battalions direct orders for the execution of urgent measures, he should at once inform the Regimental Commander of the fact with whom he should maintain aninterrupted communication."

The next two extracts are applicable to all Commanders alike, \$124. "The larger the scale of the fight, the greater the scope for individual action. The attention of Commanders should bo devoted more to carrying out their special task as a whole, than to the supervision of details. . . . But the scope allowed subordinate leaders should nerer be permitted to interfere with the plans of the Commander, and under all circumstances the maintenance of tactical order and the internal colesion of the troops should bo insisted upon." \$54. "The exercise of independence within these limits is the foundation of great results in war."

Fire Action.-At page 148 of the old Regulations we find the old Regulation view of the value of fire action. "The possibility of concentrating fire action on particular points for a short time invests it with an offensive character. It may under certain circumstances be absolutely annihilating, and may consequently of itself produce a decisice result, in any case an attack following immediately after trould thereby be greatly facilitated." How different is the position accorded to fire action in the new Regralations! Part II, \$ 13. "The infantry fight will as a rule be decided by fire action." \$30. "The action of infantry consists primarily of the fire of the extended fighting line. It is able, solely by its fire, not only to repel the enemy and prepare the attack, bat also ander certain circumstances to decide the issue."

The Germans now classify all formations under. two heads : 1st, the fighting (or extended) formation, the only one possible under modern fire; and 2 nd, close formation, the only way of concentrating largo masses preparatory to assuming this fighting formation. Iinear tactics are completely excluded, as having no place in modern tactics. They are impossible in the first and useless in the second formation. Battalion, regimental, and brigade formations all como under tho second head. The company is the only unit with a close as well as an extended formation. As to the proper rôle of close formation on the modern European battle-field, the old Regulations say, page 147: "The bodies in close formation should lay the greatest value on the retention of the troops in rank and file, the interior cohesion, the firing in mass and on the bayonet charge." New Regulations, \$13. "The delivery of fire by bodies in close order is the exception." \$18. "Fighting in extended formation and the correct application of its rarious motements, passing from extended to close order and vice $v e r s \hat{a}$, require therefore to be practised more thoroughly than the application of close formations, in which the infantry fight was formerly conducted, extended order then taking merely a secondary part." $\$ 19$. "The extended formation is the one now principally employed in action. The fight is commenced and in most cases carried through to the end in extended order. "The extended line becomes, therefore, the principal fighting formation of infantry." $\S 20$. "Close formation nevertheless still retains its full use in tho 
case of troops hold in readiness for action and for :reserres and supports to the fighting line."

The T'hree Aims.-The now Regulations speak with no uncertaio sound as to the action of infartry against the three arms.

'I'he proper application of fire action, in all and every case, is the burthen of its teaching.

Infantyy.-\$47. "In the case of infantry $v$. infantry, the result depends, apart from moral factors, on the musketry training, fire discipline, and the direction of the firing. 'The Commander's task is to bring as nany rifles as possiblo into action, or to gain the upper hand by coucentrating the fire effect of extended lines on decisive points."

Cavalvy.-\$4S. "Tho indiridual infantrs soldier should realize the fact that he is more than a match for a caralry soldier even on open and level ground, if on encountering him he is in immediato readiness to open fire. Ho need not eren hesitate to engago sereral nt a time, if he retains his calnuness and presence of mind and uses his riflo correctly as a repenter without taking his ejo off his opponent. Infantry should remain convinced that it has nothing to fear from caralrs, cren in superior numbers, if it retains its coolness and firmmess. Erery formation is suitable for repelling caralry, which admits of its being opposed by the well-aimed fire of masses at the lailt. 'The most effectual manner of recciving caralrs is to bring the greatest arailable number of rifles to bear upon it. Oniy those formations (i.e., clanges of front) which farour this need be executed against caraly."."

Artillery.-\$ sl. "In engaging artillery, it should be remembered that to this arm belongs superiority of fire at long and medium ranges. It is only at 1,000 metres $(1,09+4$ yards) that the relative conditions become equalized, and at the shortest ranges the infantry gains the superiority. Infantry should endearour to get as close as possible to artillery, by arailing itself of the formation of the ground. Infantrs fire shoold first be directed on any teams that may be visible and then on the gunners." Long-range fire is discountenanced as a rule.

Intrenching Tools.-\$52. "Artificial corcr prepared at the right time and place renders the troops and their lenders serrices, which are important and at times indispensable. It should, howerer, be subservient to the lender's plans, and should in no way gorern them." "The premature strengthening of ground is positirely detrinental and restricts freedom of movement. Tactical training is required on the part of Commanders, in order to know when and where, as well as how to intrench."

Extent of Fighting Front.- With regard to the extent of " figliting front" taken up by infantry on a penco footing, it is interesting to notice how the Germans hare solved the point in their own practical manner. \$ 25 . "Eren during tactical manœuvres, a normal front of 100 metres (the approsimate fighting front of a war-strength company) should be allowed for a company in extended order. This extension, as compared with the strength of a company, is greater 
gain that: adopted : in: war. This, however; is equalized 'by. the fact that tho fighting line is not thinned by casualties as in war."

... So mircli, then, for Part. II. Tittle need lie said of the last the third; Part-Parades, \&c.-in which: are, however, many poirts of interést; showing; as they do, how complete is the reform throughout. It will suffice to say, that complicated show morements and formations'for the edification of spectators; requiring much time and trouble in getting ap, erist no more:- $12 \frac{1}{3}$ pages contain all tho necessary instruetion for the -smart : and soldierlite - performance of all : parade duties:

I!--Bregle Calls. -The bugle calls haro likeriso becn.most carcfully revised. 'They numbered twenty-nine. Of these, thirteen hare been abolished, and five others hare been introduced. Theso are.shown in Appendices 2 ard 3 :

- Those abolished include all those, by means of which the Battalion Conmander was wont to handle the skirmishing line, which duty has now been remored from his hands to those of the company leader.

During exercises, the Commander may use calls to break off the fight, to continue the fight, or to assemble tho Commanders or their. dides-de-Camp.

In action, the only bagle calls allowed are-

$$
\begin{aligned}
& \text { Rapidly forward, } \\
& \text { Fix bayonets, } \\
& \text { Attention. }
\end{aligned}
$$

Of the dram and fife calls, threo hare been abolished and one introdnced, learing a total of twelre.

Common scuse, combined with a sound military training, will find $\Omega$ freo hand left it in erery part of these Regulations. There are, however, four things, and only four, distinctly prohibited.

Part I, § 104:-Iseaders are forbidden to use preconcerted signals with the whistle.

Part I, § 219.- The laying down of fixed formations for the deployment for action, to meet special cases, is for. bidden.

Part II, § 82.-Any further systematizing of the procedure of attack is prohibited.

Part II, § 120.-Practising particular representations of the fight is prohibited.

These prohibitory clauses are doubtless inserted with a view to guarding against the stiffening effect of time, and effectually to prevent the letter from erer frining the ascendenej over the spirit, in the application of these Regulations.

And now in conclusion let me gire you literatim and rerbatim the last "note" of the friend to whom you are-as I am sure you must feel yourselres to be-under a great obligatiou for the information he has enabled mo to put bcfore jon. That "note" runs as follows, and how far you concur in the sentiments it so cloquently and concisely expresses, the discussion which I hope will now take place, will show. 
"A careful consideration of the German Drill Regulations, 1888, cannot fail to convince us that the Germans have indeed cleared their deck for action and thrown all nselcss lumber overboard! Nothing has been retained but what will be of use in, and stand the test of war. All the cherished, truly national and traditional rigid linear tactics and spirit, inheritcd from their great King Wrederick, for ever relegated to IIistory! Simplicity and uniformity introduced into their drill and training, all non-essentials eliminated, enabling increased time and attention to be devoted to essentials, and thereby facilitating and expediting the re-incorporation of the Reserves in time of need; constant and immediate readiness for war at all periods of the training. Such are the principal adrantages secured.

"Great as has been this ware of military reform, wo may rest assured that now letter and form have bcen effectaally subjngated by the spirit, wave after wave will succed it in proper time, continually readjusting the military fighting machine and fitting it for the per. formance of its ever-clianging work."

If this be correct, as I personally believe it to be, the lesson before us English soldiers is, in all departments and branches of our profession, to "go and do likewise." 

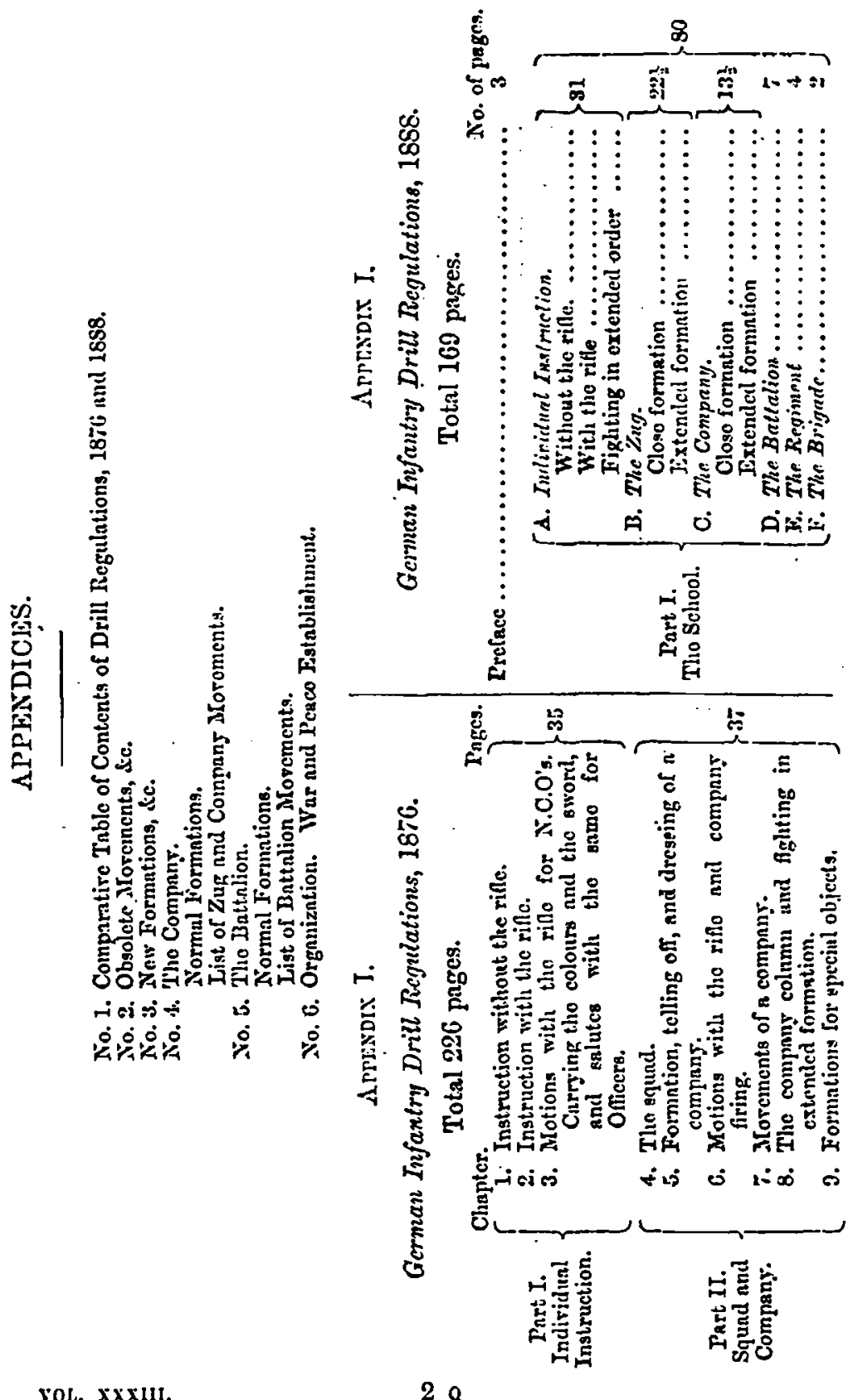


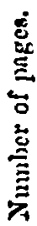
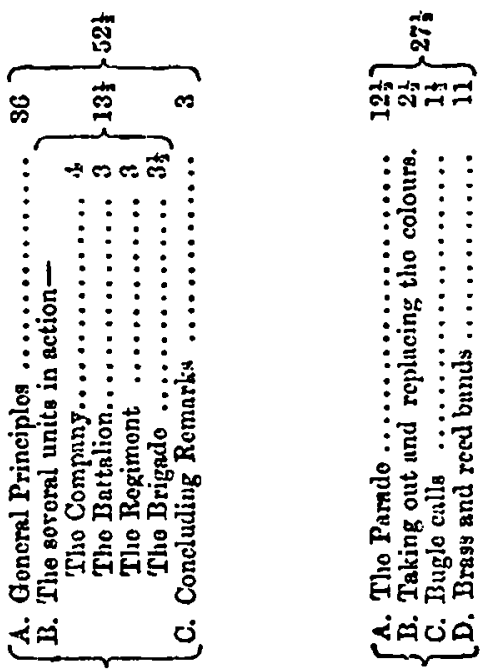

도일염

:옿 :

: sc:

:

:

:㓂:军

氞总总

동음

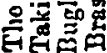

$: \vdots$

:

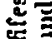

올

는

就

点产

己ู 욜

它突

¿مि0

$-i=i=5$

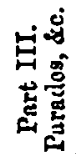

$\dot{0}=$

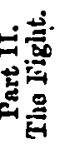

․ㅡㄹ

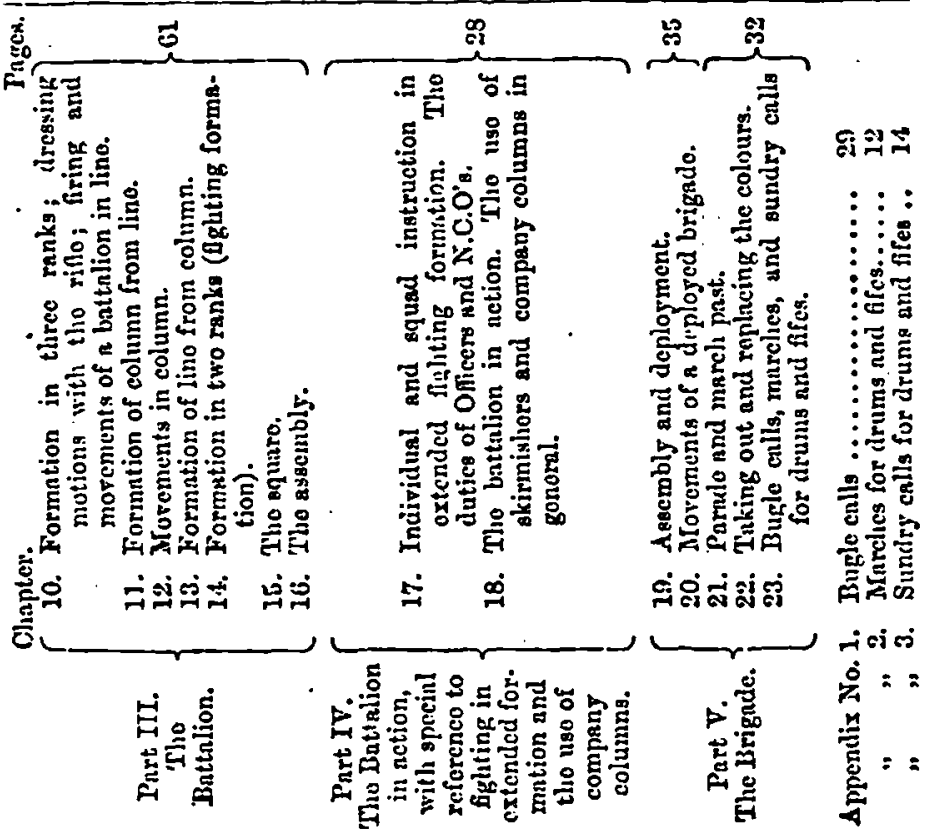




\section{ApPExDIX II.-Obsolete.}

a. Individual Instruction.

1. "Schliessen." Closing to flank bj aido stop as a practice. Incitlentally mentioned $\S 11$.

2. Manual exercisc.

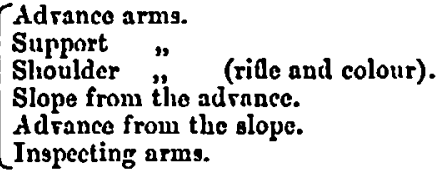

Note.-Only the order, present and slope arc retuined.

3. All cxcreises "by numbers."

\section{b. Company.}

1. The "three-rank formation."

2. Subdirision of companj into tro zügc.

3. Open aid close columns.

4. Wheeling of extended figloting line.

5. Relieving of extended fighting line.

\section{c. Batlulion.}

1. Battalion line and line morements.

2. Battalion columns at different distanceg.

3. Battalion figlting formations.

4. Attacks in columa and line supported by ekirmishers.

5. Battalion squarc.

\section{d. Bugle Calls.}

1. Adrance and rear guard.

2. Supports.

3. Stirmish.

4. Cease firc.

5. Inalf right.

6. Half leit.

7. Left wheel.

8. Right whecl.

9. Forward.

10. Unfix bajonets.

11. Rapid retire.

12. Slon retire.

13. Form colunm.

Drums and Fifes.

1. Rapid firing.

2. Cease firing.

3. Rercillé.

APPEXdX III.-New.

Individual Instruction.

"Salutc bs a sentry at the oricr. Thie rifle is graepred by the 1. "Strecken." $\left\{\begin{array}{c}\text { muzzle, and the arm cstended to the right, the butt resting } \\ \text { ou the }\end{array}\right.$ 2 Q 2 
2. During the bagonct charge, the rifle is now beld at the short trail instend of the trail.

3. The ordinars pace has been accelcrated from 112 to 114 paces a minutc.

At the double the pace is now giren as $165-170$ a minute, measuring 1 matro $(39 \cdot 3$ in. $)$.

4. In marehing " out of step" (ohne trilt) the diatance between ranks from back to breast is incrcascd from 0.61 to $0.80 \mathrm{in.}$ ( $251031 \frac{1}{2} \mathrm{in}$.).

\section{Company.}

1. The two.muk formation.

$\because$ The subdivision of the company into three züge.

3. The company wheel, alwajs exccuted nt the clonble aml out of etep.

4. All interior morements of the company exccuted out of atep.

5. Normal colunn distances of seren paces.

i. The company leader is mounted, when the comp.nny forms part of a larger unit.

7. The handling of the compang in the fighting line rests solels with the comprany leader.

Battalion.

Normal Formations. $\left\{\begin{array}{l}\text { 1. Double column. } \\ \text { 2. Deep " } \\ \text { 3. Brond " }\end{array}\right.$

Bugle Calls.

1. 4th Battalion.

2. Cominander's call.

3. Aide-de-camps' call (orlers).

4. Rouse.

5. Retreat.

Drums and Fifes.

1. Kousc.

\section{ArPENDIX IV.-The Company.}

Normal Formations.

1. Companj column $\left\{\begin{array}{c}\text { scren paces from front rank } \\ \text { to front rank. }\end{array}\right.$

2. Iinc.

Alorements.

11. Zng-

1. Marching in line $\left\{\begin{array}{l}\text { adrancing. } \\ \text { retiling. } \\ \text { diagonal mareb. }\end{array}\right.$

2. Wheeling in line.

3. From line into $\left\{\begin{array}{l}\text { fle column } \\ \text { section column }\end{array}\right\}$ and back.

4. Changing from one culunn into another.

5. Column changing direction. 
b. Company-
1. Marching in line $\left\{\begin{array}{l}\text { adraneing } \\ \text { retiring; } \\ \text { diagonal maneh. } \\ \text { mliceling (at the double and out of step). }\end{array}\right.$
2. From line into $\left\{\begin{array}{l}\text { file column } \\ \text { section column } \\ \text { company column }\end{array}\right\}$ and back.
3. From cowpans column into $\left\{\begin{array}{l}\text { file coluun } \\ \text { section column }\end{array}\right\}$ and buck.
4. Company column $\left.\begin{array}{l}\text { morements } \\ \text { to a nank in }\left\{\begin{array}{l}\text { flo } \\ \text { sections }\end{array}\right. \\ \text { change of direction. } \\ \text { whecl. }\end{array}\right\}$ und baek.
5. Compang column, relucing its front by half 2 ügc and back.
6. Square. (Jlorentents ill square.)
7. Bajociet charge.

\section{Arpesdix V.-The Battalion. \\ Normal Formations.}

Companies in battalion colunans are insariably formed in compauy colunus.

1. Duuble columu $\{$ 1. Fur purposes of assembly and

1. Double column .. $\{$ 2. For morements out side the ephere of the cucmy ' fire.

$\left\{\begin{array}{l}1 \text {. For purposes of assembly, when a nurrow frout is } \\ \text { required. }\end{array}\right.$

2. Decp column ... 2 2. When a march is to be commenced from the place of assembly.

1. For parade purpozes.

3. Brual colurn .. $\left\{\begin{array}{l}\text { 2. Ouly to be uscd when brosd front is required } \\ \text { 3. Not suitable for battislim clange of front. }\end{array}\right.$

4. For reassembling after an action.

\section{Movemerts.}

1. Clanges frow one colunin into another-

From double column ivto $\left\{\begin{array}{l}\text { Decp column. } \\ \text { Broatl column. } \\ \text { From deep column into }\end{array}\right.$
Fouble column.
Broad column.

2. Morements in column:-
Changes of direction by
a. $\left\{\begin{array}{l}\text { whecling } \\ \text { diagonnl mareh }\end{array}\right\} \begin{aligned} & \text { bs word of } \\ & \text { conmmand. }\end{aligned}$
b. Indication of point to march $\mathrm{m}$.

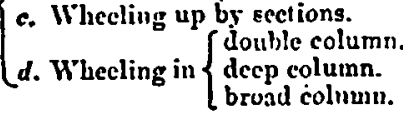




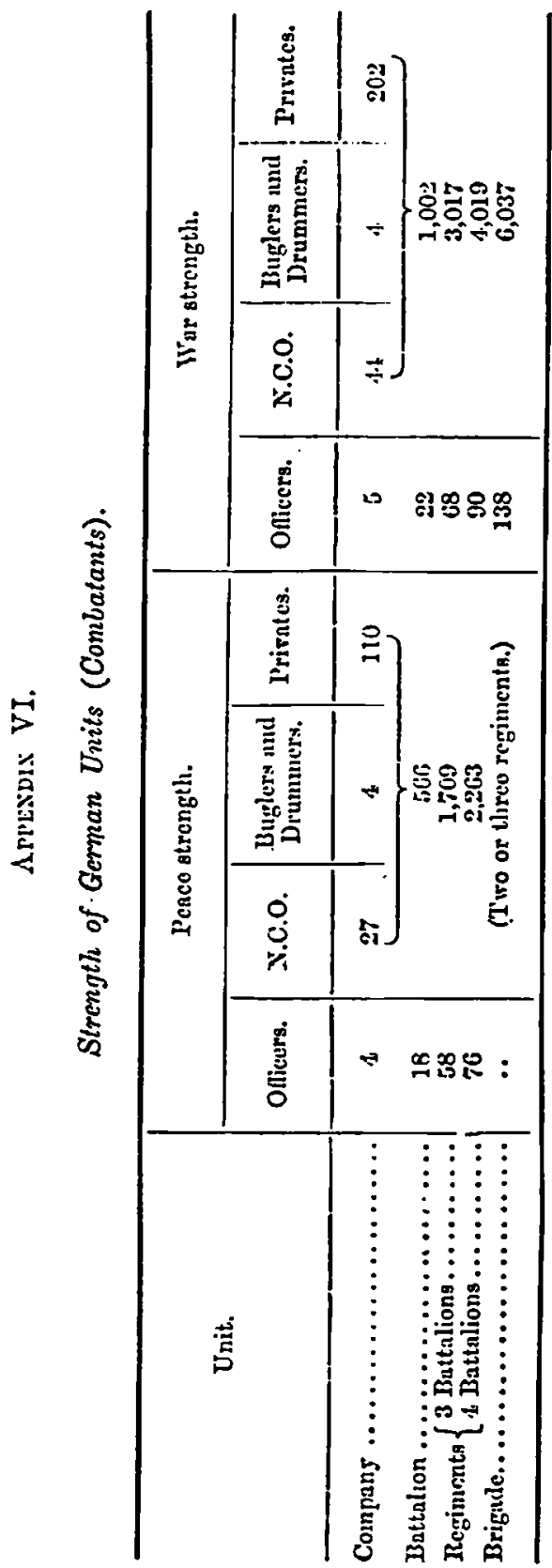


Coloncl Sir Lryiter Grayay, Bart. : Mr. Chairman and gentlemen, I wish to male a few remarks on the rery intercsting lecture which my friend Colonel Lonsdale Hal: lans giren us. I understind from what he said that the substance of it was communicated to him by a friend to whom we nilst be rery mueh indehted for the trouble lie has taken. I would first of all remark that $I$ think there has been some slight exaggeration by the writer of that paper with regard to some of the minor details of change, which do not matter much, perlaps, but still thes are of eome importance. For instance, any one who had heard that lecture without knowing anything about the tactics of the Corman Army would suppose that it was a new thing to form the compuny into three züge, but that is not so. Ercr since I have known anjthing about the German $d r n y$, which is more thin twenty jears, and $I$ ilo not know how:long before that, the company was originally formed up on parade three decp and in threc züge, but as soon as it was prepared to clrill or manucurre, b5 a couplicated arrangement the third rank was done away with, and the two $z$ üge, of which it wus originally composctl (what we should call half companies), were divided into three ziige. I guther that the three-deep formation has been lone away with allogether; if so, I congratulate the German Amis on the eluene. It alirays secmed to me a most extraordinary thing that practical soldiers like the Germans should retain their threc-decp formation cren for parade, entailing as it did the change into the two-decp formation before the coupliny began to manourre. I am glad that they lane done awas with this complicution, nun I think we may reflect with sous pleusure unon the fact that we in Finglund who are not, as a rule, looked upon as lcading the way in wilitary matters should,-at any mate, hare been fur before the Germans and others in this instance. A rery long time ngo, at the beginuing of this century, we aclopted the two-deep formation us a nurmal formation, nind no doubt that led to the great derclupment of fire which we used rith such effect in the wars of that period, and rlich gitve us grcat superiority orer our cnewies. There is another little detail which the rriter of the article refers to in a umner which would lead me to suppose it wis something new, but it is no norelty. I refer to the "marching without stel," what we sliould call "Inarching at cusc," which hits nlways been practised in our Arwy nud in that of Germany cier since I can remeuber, not, howerer, to the same extent by us ns by the Germans. They call it marching without step. We used to, and I beliere etill, expect the men to keep sfep eren when marching at ease; and indeed they generally do so of their own accord, becausc they find it pleasanter to keep step than not, but we allow all the ofher relasations permitted by the Germans when marching without step; these are, however, trilles. The great point brought ont by the Iccturer is the spirit which inspires the changes now ulade in the field erercises of the German drmy. The inspiration, by-the-bye, does not come from abore, it comes from below, dating from the jear 1866 . During the war of that year, although the leaders of the Arwy adhered to a great many of the old rules, to which they were vedded, and were arerse to changes, there were, nerertheless, enlightened epirits in the lrussian drny who saw that many of those rules were: obsolete, and erer since 1866, down to the year 1859, there has been a constant confliet between the Reforming and Conservative parties in the Army, the former, as a rule, comprising the younger OAlecrs, the latter, those of a higher degree. A great many of those changes which are now ollicially adopted in the Regulations of the German Army had been practically in use before. 'There is no doubt that the battle before Metz taught a great lesson, and prored the necessity of great tactical chinges which had hitherto been resisted by the chicfs of the Prussian Army. The principles which thus rccommended themselses were to a certain extent recognized by authority, and were carried out by the more enlightened Officers during the remainder of the war. From that time onwarls there has been constant fretting on the part of the military reformers to work those changes, which hare at last made their way, ant which are now recognized and authorized br the present Jegulations. But I do not think there is a single point nentioned by the lecturer amongst the more iwportant changes in German tactics which had not been -trongly udrocated for years by one or other of their military writers. I think we may apply this lesson to ourselves. We have not had the sunce adrantages as the Cierman $\Delta$ rwy is haring to fight against cirilized troops, so that we hare not 
learned by experience how necessary many of the refornis were sometinics; anil, morcurcr, what fighting our $A$ ray las had, and perhaps is likely to have for sonin: time to come, lang been against an enems to whom the scientific methods of modem warfare are not alwajs applieable. 'This is bad for us in soune way'; it leads us mather to neglect the molern scientific mode of fighting and to adhere to our oll forms, which under certain circumstances, against the oort of cnemy that ne encounter, are inore advis:able. Therefore I think it is most iunostant that the altention of our soldiers should be frequently called to what is really the scientifis: morle of fighting, and the mole that we should hare to practise if we erer cngage sy:iinat a liuropean eneny. I think on that account the way in which Colonel fial: las summarized the authorized changes in the German Amy is of rery great importence, and I hope that those in command, the higher authoritics of the Army in this country, will take notice of what has been done abroal by a nation which has had the best possible opportunity of julging of what is realiy neful in war, and that wo shall not lag belind. At the same time, Officers who command our troops in action against Zulus or Soudavesc, or auy similar nutngonists, will, duubt. less, hare the intelligence to modify the process which they shonld use against a cirilized cnemy to what is required for engaging sarnges.

Colonel LoNsdals. Hine: There is a junior Offiecr present whom I nas rent ure to call on, Lieutenant Fillison, of the Staff College, wlio has spent most of his vacation lately in Germany. I dare say he would be nble to give us some practical information as to the working of theso Regulations, and how they are acecpted in the German Army.

J.icutcuant G. F. Fir.isox: General Frakiue nnd gentlemen, the only thing whith indues me to take a part in this discussion is the fuct thit since the intro. duction of the new Drill Regulations into the German drmy, I have liad opportunities during $n$ recent sisit to Germany of hearing German Officers discuss them, and also of secing something of the training of the recruits under the new system. I may first of all state that the opinions which I have heard espressed bJ German regimental Officers hare been entirely farourable to the new Regulations : they likn them, and they say so. They thoronghly realize that the increased demands on the intelligence of the indiridual soldiers hare by no means lightened their tast in Iraining them. Frery company commander nalizes too that increased responsibility is thrown on his shouklers, not only in haring to train his men up to a higher standard of indiridual excellence, but also in the fight itself, as the company, as stated by the lecturer, has now practically taken the place of the battalion as a Iactical unit. The German regimental Offecr is accustomed to and relcomes responsibility. It has been remarked in England that the present Regulations with their broad generul principles make great demands on the personal intelligence of the reginental Oniecss, but I think that sing one who knows Qerinan Otlicers will feel conrinced that they will fully justify such clemands being made on theur. Indecl, under a system where it is an absolute certainty that, unless thes cun satisfy such demands their serviecs will be dispensed with, it eannot be otherwise. And I think it is just that responsibility which really was the main cuuse of the change, for, as Sir Lumley Gralsam said, these changes lare been brought about by the lower ranks. The regimental Ofticers hare a responsibility and thes feel it, and it is they, to n great extent, who hare called for the sinplification of the drill. 'They are the men who realls feel the erils of the old orter of things, and haring the responsibility, they were realy to say what they thought. It certainly is, to a great estent, the lower ranks of regimental Officers who called for, nnd hare now got, theso changes in the drill, becanse it is on them the responsibility falls. Witl regard to the training of the men, I should like to say a few ronds. The worts on which the German company conmander has to bisc the training of his recruits are : (1) Drill Regulations; (2) the MIusket ry Regulations; and (3) the Gymnastic liegulations. The Qerman recruits join in Norember, and by the following Jrarch they hare to be what we should call "Irained collliers," as far as theso subjects, namely, Drill, Musketry, and Crmnastice, ure concermed. Allded to this is also the fuct that under the new Regulations each recruit must be thoroughls grounderl in the theory and practice of the soldicr's duty in modern warfare, that is to say, in fighting in extended order. To attain so much in so short a time, a proper dietri- 
bution of time and daily tasks is one of the foremost problems for those on whom the responsibility falls, namely, the company commanders. That some Oficers do find a difficulty in doing this is erilleneed by the fact that there have nppeared in (iermany various short works published by Oficers who hare rorbel out a system for theuselve's; thesc works being for the lise of their commules who fiud $n$ difficulty in bringing their men up to the given standard in the giren tiwe. To show what the ain of such books is, let ne quote the words of one of thicse w riters, Captain ron Busse, a German Oflicer." IIe says: "The task of those to whoun the training is entrusted increases in proportion as more is expected of the indirilual soldier. They hare to work on a material differing in its quality to no considerable estent from that of former days, when what was expected of it was substintially lcis." In eperking of the increased demands now vade on the intelligence of tho soldier, ho is referring to what the Qermans call the independent use of the rille by the soldier in the fight, a term which ono constantly sees in German books. Ife says that he has been induced to publish this work as "it cannot be otherwise than welrantageous for the truining staff to lare at its disposal a definite plan on which the young Ollicer and non-commissioned oflicer enn confidently continue to work without haring to umbe experiments for themselres, experinents which are doubtful ind not alwiag accompanicd by aucecss." In conclusion, I would only point out what in the German system abore all strikes an English regimental Oflicer. Those pwints are: (1.) 'Ilic absolute and unqualified responsibility of the company communder for the training and discipline of his men and also in the fight. (2.) Tho marrellous intelligence brought out by thcoretical instruction in the non-commi:sioned oflicers and men. (3.) 'The individual training, the Einzelausbildung, of tho necruit. In all these works on the training of the men, that is the term which ono so constantly secs employed. In musketry ilrill, and everything else, the recruit is first of all trained individu:ally and singly. And (t) the couplete concentration of the training, that is umler the new liegulations, on the objects of the fight, on that and for a hich the soldier exists, namely war.

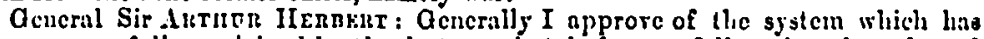
becn so carefulls esplained by the Iecturer, but before we follow the plan ndopted by the Germans, the organization of our battalions nust be changet. If the companies are to become quisi-independent units, the number of companies in the battalion must bo reduced. This has for ycars past becn alrocated by many Ofiecer, but the change has been seriously objected to bs many others. If the company is to become a tactical unit, and if the Captains aro to hare the great indiridual responsibility giren by the German Regulations, the strength of esch company must be considerably increased. The Bat talion Commander could not equally well gire the necessary instructions relatire to the modo in which the attack was to be conducted to eight company leeders as to four. If ho did, greater confusion would result, as there would naturills be a greuter difference of opinion 33 to the manner in which the instructions should be carried out by the Captains if there were cight than if there wcre four leaders in cach battalion. Therefore, so long 23 the present organization continucs it would be rery nuadrisable to go as far as the Germuns hare in delegating authority to company leaclers. Int anjone curefully read our neir drill book, and he will fidd that a great quantity of the so-called top liamper has been thrown orerboard, and that a long step has been taken in the right direction. For the present it appenrs to me we hare gone far enough, and I hopo wo maty more on gently. The Qermans adraneed rery elowly in their reforms; twenty jears hare elipsed since the agitation for changes in the drill commenced, and they hare only recently been officially approred of. I entirels anree that it is iulpossible to lay down any regulations which could be carried out in action and which rould pre. rent compunies and cren battalions becoming mixed together when attacking in extended order. What is required is to accustom both Ullicers and men to work when mired with other companies, and when an oppportunits occurs to rally and re-form on their own Uilicers. This I and other Ollicess hare enclearoured to do. When I commanded the csmps of instruction at the Curragh, I made a point of suixing up the companies and eren battalions in attack formstions; both Onicers and

1 Sce ante, p. 5i2. 
men soon became accustomed to more and manceurre even when interrringled with other companies, and when opport unities occurred to rally on their Olficers and get into order. It will therefore be scen that we also have tried many manceurres before they have been oflicially adopted. It appcars to me a mistake in the German drill, eren in company formations, to adhere to the touch-on rough ground the touch cannot be maintained, and as baltles are not fought on parade-grounds, what cannot be carried out on service should not be practised in time of peace. So long, therefore, as our battalion remains the tactical unit it would not in my opinion be desirable to delegate to company Commanders the powers and responsibility confided to them by the German Regulations.

General Sir Lixtoms Sinuoxs, G.C.B. : There is vers little I can say in addition to what has been said. The lecture is one of extreme interest and one which muat be beneficial in inducing Officers to etudy the system in rogue in Germany. I quite agree with Sir Arthur IIerbert in what he has said as to the present constitution of the battalion; jears ago in this theatre a lecture was read at which I think I pre. sided, or at any rate was present, in which the question was discussed as to the formation of the battalion, and I felt conrinced at that time as I do now that the best constitution of a battalion for manceurring in tle field is one in which it would be dirided inlo four companies. It las many adrantages in other respects. I beliere if properly carricd into effect it would simplify the eystem of promotion, as I stated before Lord Penzance's Comnission, by establishing a betler proportion between the number of Majors and Ollicers of inferior rank. It has this great adrantage in the field, that when the lines of skirmishers are extended, their support depends upon the Oflicers commanding the companies, the men of which are in the most adrauced line, and thus men who are accustomed to work together and belong to the same companf; get mired up in the first instunce in the fighting line, not an strangers; I beliere it would bo of very great adrantage that the supports slould be formed from the company which furnishes the fighting line. I do not know that I hare any further obserrations to make except that haring been at the German mancurres fire or six jears ago I was rery much struck by the facilities afforded by theirssstem of command, by which the details of attack are left to subordinates for changing the direction of the morements of rers large bodies of troops, and transferring them from one part of the field to another, thus illustrating the adrantages of their organization for the transmission of orders, an inportant but by no neans easy object to attain when in action.

Colonel LOXSDALE IraLE : First of all with regard to the question of large companies; I remember about eight or ten years ago discussing the subject with a distinguished Officer, who asked me not to go in for four companies, because be said if once you take four companies you will hare the British taxpager reducing your Captains by one balf, and it is important that we should keep as many Officers as possible. It is perfectly ccriain that if you publish to the world that you will only hare four companies, the next radical morement in the Iouse of Commons will lea: to a reduction of Officers. I greatly agree in what Sir Arthur Ilerbert has said, but I hare nerer adrocated it because I beliere the loss of Officers would be a rery serious thing. With regard to the lecture which I have been prosy for to-day, while most cordially agrecing with it, I think I ought to rewind you the s5stem which it describes is purely an ideal nnd untried system. It is not like the system which many of us described after the war of 1570 . which had been prored by the results. We hare to wait for $n$ campaign to see how this extreme individualism and excessire subdirision of command will work. We hare nerer eeen ungthing tried in war like the ideal, and may I say the somowhat Utopian esstem which has been put before us in this lecture. II friend who was unable to gire this lecture is, I think, a great believer in general principles. IIc las, howerer, nerer taught, and I hare taught all my life, and I cun only say this, it is ca+y onough to make men get loold of a certain amount of rule of thumb and to apply it, but gire mo a man who can grusp principles, especially young men between twenty and thirty, and can apply them properly, and you gire me a man of more than ordinary ability. There is nothing so diticult as for young fellows to learn to apply principles to practice; From great experience in examinations I may say that if I want to stop Captains; promotion or.Lieutenants' promotion, I merely lave to gire applied questions on 
gencral principles only, and fer will answer. If I combine the two, crergbody answers the rule of thumb question, and only the best inen, and they are few, answer tlie applied general principles. In order to apply general principles you muat have a great amount of practice. In the German Ariny they are always practising and therefore they can be constantly trjing to apply these principles to practice and be corrected by their older soldiers. In nn ariny like our own which hns no opportunity of practising in. the ficld, to throw anjthing like this at their heals and sas, "Were are principles for you, you nust go to principles," I am afraid would lead to disaster. We must not gire up altogetincr rule of thumb as well as the inculcation of gencral principles. It is usual to gire a rote of thanks to the lect urer, but I haro General Ershine's permission to alter the custom on the jresent occasion. I will therefore ask if I may be allowed to convey the thanks of this recting to uny friend who lias furaished the matcrinl for this lecture.

Tle Charress: Gentlemen, Colonel Hale in the first part of the paper to which you hisc been listening stated that it was the intention of the Council of this Institution to hare a paper included in the promramme relative to the recent clanges which had been authorized in the Drill Regulations of the Gerwan drms, but some unfortunate diffictalics occurred, and Colonel IInle very hindly undertook to get us out of them, and the present paper is the result of what he undertook to do. You will obscrre that in the paper he describes himsclf as simpls the mechanisin of the telephone. Well, I think lac nust find himsclf in a very norel position if that is the case, bccause anj person more unlike a picec of mechanism in this world I cannot imagine than Colonel IIale. As far ns my obserration gocs whenerer he appears in this theatre he gires us the result of the working of the rery fertile brain with which Nature has endowed him. I au quite sure it would be much more consonant to his feclings to come here and gire us an original paper of his oxn than one of another person, and I hope before long that he will find an opportunity of doing that. With regard to the concluding parts of his lecture, wherein he points to the (ierman Army as un example to ours, and calls upon us to follow their cx:mple, I hare o:tly this to sar, that it scems rery gool adrice. I should strongls advocate it mysulf, but at the same time we sliould not proceed to act upon it without great circumspcetion, for we must recollect that what misy work very well in tho German Army night not be at all suitalsle to ours. With this rescrration I think his advice is rery seasonable, and I think it luust be a sitisfaction to him, as I am sure it is to myself and to niost of us, to fiud that our War Office has anticipated thut adrice in the manual of drill which they have recently put forward. Whether in the compilation of that manual the work of excision has been carried to the full extent that was required, I am not quite prepared to say. Personalls, I should have liked to see a few more things eliminated from the old book, but at all erents the new book is a great allance on wliat we hare been nceustomel to. I quite agree w ith Sir Lumley Graham that the reform which has tatem place in the German Arms has worked from the luwer ranhs up to the higlier ones, and what holds gool with them $I$ an quite sure lolis good in our awn Arms. I nill not detiin you further. We hare alreals thankel the unknown gentleman who has helped Colonel Hale in this lecture, and we ought not to omit to thank Colonel Hale himself for coming hero and giring us the benefit of it.

Nore. -I think Sir L. Graham misunderstoud my reference to the zug. The zug lias assuredly cxisted for years, but it t taining as a unit appears in the exercise for the first tive now. The marehing "Olıne Tritt" is not tliat also of former days.l. d. II. 